\title{
Eliminating Cyanobacteria and Controlling Algal Organic Matter-Short Notes
}

\author{
Djamel Ghernaout ${ }^{1,2 *}$, Noureddine Elboughdiri ${ }^{1,3}$ \\ ${ }^{1}$ Chemical Engineering Department, College of Engineering, University of Ha'il, Ha'il, Saudi Arabia \\ ${ }^{2}$ Chemical Engineering Department, Faculty of Engineering, University of Blida, Blida, Algeria \\ ${ }^{3}$ Département de Génie Chimique de Procédés, Laboratoire Modélisation, Analyse, et Commande des systèmes, Ecole Nationale \\ d’Ingénieurs de Gabès (ENIG), Gabès, Tunisia \\ Email: ^djamel_andalus@hotmail.com
}

How to cite this paper: Ghernaout, D. and Elboughdiri, N. (2020) Eliminating Cyanobacteria and Controlling Algal Organic Matter-Short Notes. Open Access Library Journal, 7: e6252.

https://doi.org/10.4236/oalib.1106252

Received: March 23, 2020

Accepted: April 12, 2020

Published: April 15, 2020

Copyright $\odot 2020$ by author(s) and Open Access Library Inc.

This work is licensed under the Creative Commons Attribution International License (CC BY 4.0).

http://creativecommons.org/licenses/by/4.0/

\begin{abstract}
Coagulation and flocculation processes could reduce particulate algal cells efficiently, but they are not so performant in dealing with solubilized algal organic matter in potable water factories. This work reviews the main findings found in recent publications. Many techniques used in the water treatment industry encounter the problem of microalgae lysis, toxin release, and degradation. Indeed, chemical coagulants such as alum and pre-oxidation injecting chlorine can trigger demolition to algal cell integrity leading to the release of intracellular organic matter. As suggestion, chlorination could be decreased to the disinfection (i.e., before sand filtration) averting pre-disinfection and keeping the post-disinfection. Moreover, algae recuperation instead of its removal in drinking water treatment plants remains an encouraging outlook especially if the surface water arrives from dams where algae blooms happen usually. Algae remain a sustainable energy resource with a huge capacity for $\mathrm{CO}_{2}$ fixation. The micro-algae could be developed in photo-bioreactors or in open ponds. A fresh attracting domain of investigation would be fast and simultaneous algal biodiesel production with drinking water treatment in the biodiesel production/water treatment plant without chemicals use.
\end{abstract}

\section{Subject Areas}

Biological Chemistry

\section{Keywords}

Algal Organic Matter (AOM), Extracellular Organic Matter (EOM), Intracellular Organic Matter (IOM), Disinfection By-Products (Dbps), Enhanced Coagulation (EC), Microcystins (MCs) 


\section{Introduction}

Because of climate alteration and plenty of nutrients, both recurrent eutrophication, and the outbreak of algal blooms and phytoplankton development in surface water remain of universal worry [1]-[6]. The particulate algal cells are reduced fully $(>95 \%)$ throughout coagulation/flocculation techniques in drinking water treatment plant (DWTP) [7] [8] [9] [10] [11]; nevertheless, solubilized algal organic matter $(\mathrm{AOM})$, which comprises both extracellular organic matter (EOM) and intracellular organic matter (IOM), stay not reduced well trough coagulation [12] [13] [14] [15]. Categorized as the autochthonous natural compounds in water, AOM contains polysaccharide, proteins, and humic-like substances [16]. Further, AOM has a considerable contribution to the aquatic ecosystem [17] since an essential fraction of NOM incorporates AOM [18]. Therefore, AOM brings about several issues in potable water treatment techniques like augmented coagulant request, development of biofilm provoking fouling of the membrane [19] [20] [21] [22], blocking the activated carbon adsorption sites, and augmented generation of precursors for disinfection by-products (DBP) through chlorination [12] [23]-[30]. While a great part of the at hand publications concentrated on the DBP production from allochthonous natural organic matter (NOM) from detritus materials and vegetation, at most restricted investigations handled the DBP generation from autochthonous NOM because of phytoplankton development; a thorough investigation is needed to formulate treatment procedures in DWTP [1] [31] [32].

The EOM is existing at all steps of growth of the phytoplankton, chemical coagulants like alum and pre-oxidation employing chlorine (to ease better reduction through coagulation) may trigger demolition to algal cell integrity conducting to the liberation of IOM, which induce taste, odor and toxicity to water [1] [33]. A bigger quantity of trihalomethanes generation happened because of the liberation of IOM throughout pre-oxidation prior to coagulation [34]. IOM may as well be liberated to treated water if coagulated species stay at the bottom of the sedimentation basin. Nevertheless, the contribution of IOM vs. EOM on the coagulation and disinfection by-products formation potential (DBPFP) stays not well-determined because of the shortage of thorough control researches. Opposed findings are mentioned in the publication on the type of EOM and IOM and their efficiency in water treatment technologies [35]. Algal IOM was discovered to be mainly hydrophilic (HPI) [16] showing small reduction capacity throughout coagulation; however, IOM of Microcystis aeruginosa was found to be more hydrophobic (HPO) than EOM [36]. On the contrary, algal EOM may operate like flocculation aid enhancing the coagulation performance [37] [38] [39]. Further, EOM may produce chelate complexes with metal coagulants, greatly augmenting the requested injection and decreasing the treatment performance [40] [41] [42]. Consequently, the impact of AOM on coagulation in water treatment stay paradoxical and particular to algal species [43] since the distribution of HPO and HPI portions of AOM changes following the nature of 
algae and phase of development [1] [44].

Until their time, Zhao et al. [1] affirmed that there has been no methodical juxtaposition of DBP generation pursued via coagulation below similar treatment circumstances for various species of algae and cyanobacteria. Goslan et al. [45] focused on the DBP generation from only EOM of three cyanobacteria, one diatom, and one green alga. Nevertheless, they did not consider the influence of coagulation on the elimination of EOM. Wide-ranging monitoring researches are required to locate the actions of particular $\mathrm{AOM}$ arising from frequently observed, abundant algal species in surface water, their reduction employing coagulant injections applicable to potable water treatment, and following DBPFP estimation [1].

This work focuses on the main achievements realized in the field of removing algae and controlling AOM. Special interest will be dedicated to the enhanced coagulation (EC) in terms of evaluation and amelioration. Electrochemical technology will be shortly discussed as it is employed in the field of algae harvesting. The influence of water treatment technologies on cyanobacterial integrity will be briefly introduced. Averting chlorine use, and instead of eliminating algae, harvesting it for biodiesel production will be presented as future trends.

\section{Coagulating Algae and Cyanobacteria and DBPFP of EOM and IOM}

Zhao et al. [1] evaluated the best coagulation circumstances utilizing alum for both EOM and IOM of six diverse algal and cyanobacterial species. They tried varying coagulation circumstances like alum dosage, $\mathrm{pH}$, and initial dissolved organic carbon (DOC). Reducing DOC via coagulation matched fully with the AOM hydrophobicity. The DBPFP of different portions of AOM was assessed following coagulation. Even though higher reduction happened for HPO AOM throughout coagulation, particular DBPFP, which changed from 10 to $147 \mu \mathrm{g} / \mathrm{mg}$-C is higher for HPO AOM. Of all the six species, the highest DBPFP happened for Phaeodactylum tricornutum, plentiful marine diatom species, but is ever more observed in surface water.

\section{Enhanced Coagulation (EC) Process: Assessment and Improvement}

The fast decay of water quality is a grave menace and simultaneously constitutes a challenge for scientists for settling the issue wisely via forward-looking coagulation procedures [46] [47] [48] [49]. Following a short analysis of the usage of coagulation in water treatment and wastewater treatment, Sun et al. [50] studied the link between water and energy [51] in EC. EC alludes to the method of elevating the reduction rate of organic matter $(\mathrm{OM})$ via augmenting the injection of coagulant and managing the $\mathrm{pH}$ degree under the premise of making sure the reduction of turbidity throughout the traditional coagulation treatment of water treatment (Figure 1). Sun et al. [50] focused on the global presentation of the 
pathway of EC and the technique of EC (Figure 2). They reviewed energy consumption and the estimation of the EC method from the points of view of technology, economy, and environment. They discussed the importance and objective of EC, and the advance trend of EC.

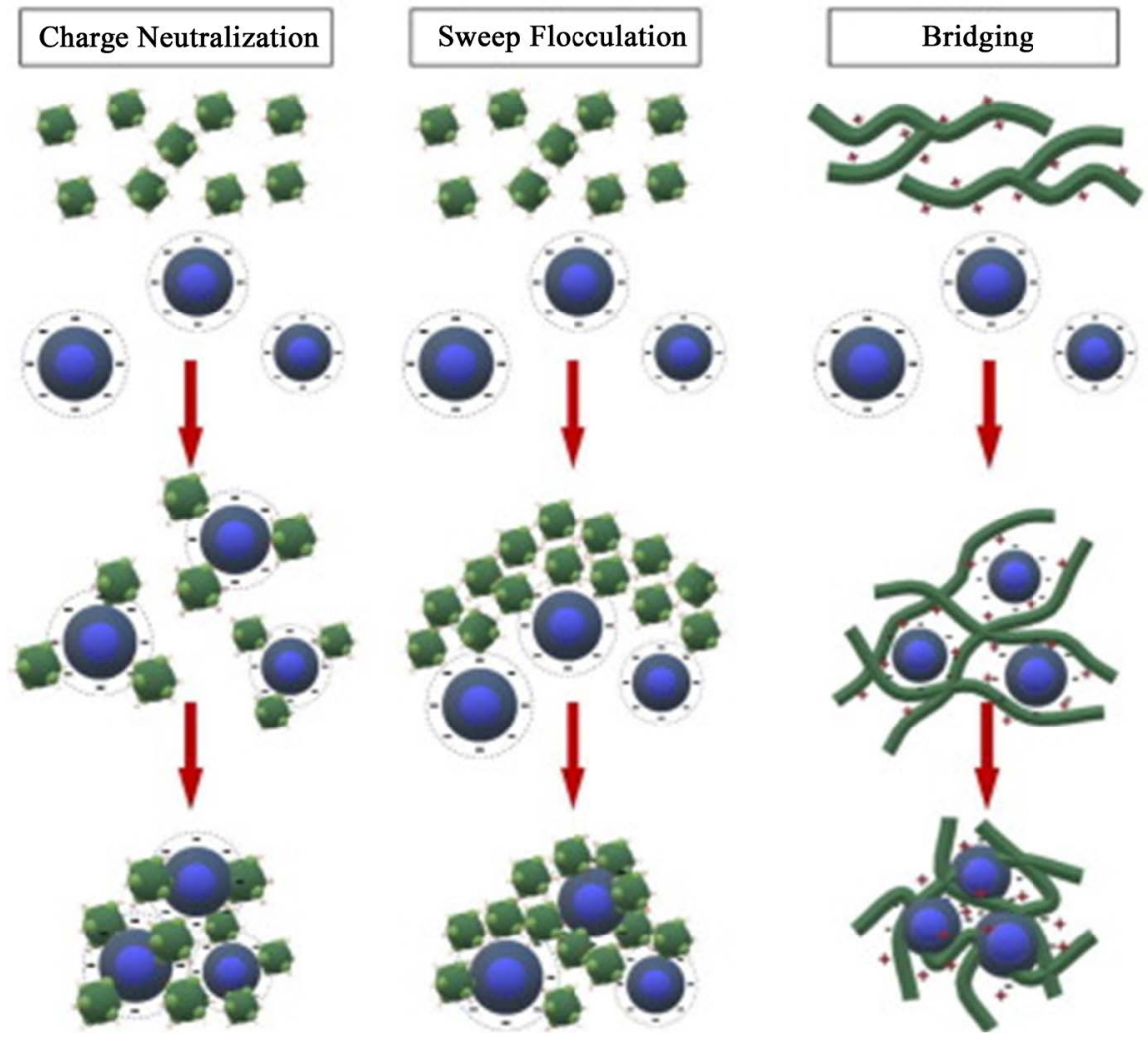

Figure 1. Pathway of EC to eliminate OM [50].

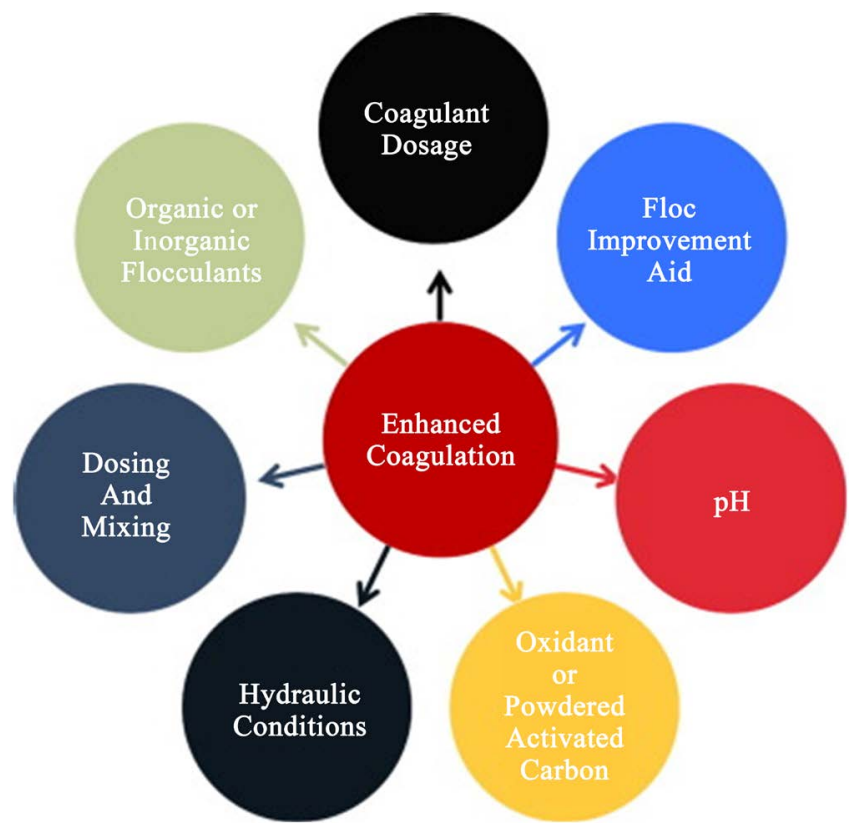

Figure 2. Procedures for attaining EC [50]. 


\section{Enhanced Coagulation (EC) for Treating $M$. aeruginosa}

Liu et al. [52] studied the implementation of EC with persulfate/Fe(II), permanganate and ozone for Microcystis-laden water treatment. They juxtaposed two oxidant dosage procedures in matter of the organic reduction effectiveness: a simultaneous dosing strategy ( $\mathrm{SiDS}$ ) and a successive dosing strategy (SuDS). To regulate the oxidant species, they examined oxidant doses and oxidant dosage strategy, the zeta potential (ZP), floc size and dimension fraction, potassium liberation and organic reduction performance throughout the coagulation of algae-laden. They found that ozonation provokes the most serious cell lysis and decreases organic removal effectiveness as it liberates intracellular organics. Then, ozonation may induce the liberation of odor compounds like 2-methylisoborneol and geosmin. With augmenting injections, the efficiency of contaminant reduction throughout coagulation ameliorated via persulfate/Fe(II) or permanganate did not observably get better, which proposes that a small injection of persulfate/Fe(II) and permanganate is the best procedure to ameliorate coagulation of Microcystis-laden water. The SiDS accomplishes better than the SuDS since more Microcystis cell lysis happens and less DOC is reduced when oxidants are introduced before the coagulants.

Similar research was performed by Lin and Ika [53] who worked on EC polyaluminum chloride $(\mathrm{PACl})$ coagulation for reducing $\mathrm{DBP}$ precursors.

\section{Juxtaposing the $\mathrm{H}_{2} \mathrm{O}_{2} / \mathrm{Fe}$ (II) and $\mathrm{H}_{2} \mathrm{O}_{2} / \mathrm{Fe}$ (III) Methods for Eliminating Cyanobacteria}

For Zhang et al. [54], pre-oxidation EC could be more efficacious at reducing algae than conventional coagulation. Nevertheless, its utilization is inhibited via elevated oxidant/coagulant use and the consequent potential health hazard, in the form of AOM liberated throughout oxidation. To reduce cyanobacteria and at the same time maintain cell integrity, $\mathrm{H}_{2} \mathrm{O}_{2} / \mathrm{Fe}(\mathrm{II})$ and $\mathrm{H}_{2} \mathrm{O}_{2} / \mathrm{Fe}$ (III), which have been broadly employed to decompose organic contaminants in waters [55] [56], are suggested by Zhang et al. [54]. They followed the elimination effectiveness of $M$. aeruginosa below different oxidant/coagulant injections, AOM liberation and cell safety, as well as floc production and morphology with such concomitant oxidation/coagulation techniques. Their findings depict that the reduction performance was greater than $95 \%$ with $\mathrm{H}_{2} \mathrm{O}_{2} / \mathrm{Fe}(\mathrm{II})$ and $\mathrm{H}_{2} \mathrm{O}_{2} / \mathrm{Fe}$ (III) below $100 \mu \mathrm{mol} / \mathrm{L} \mathrm{H}_{2} \mathrm{O}_{2}$ and Fe (Figure 3). Further, neither process was observed to deteriorate the algal cells in $50-200 \mu \mathrm{mol} / \mathrm{L} \mathrm{H}_{2} \mathrm{O}_{2}$ dosing levels. Moreover, they discovered that AOM, involving microcystins (MCs), was well-dominated thanks to the oxidation of $\mathrm{H}_{2} \mathrm{O}_{2}$ or hydroxyl radicals, and in-situ $\mathrm{Fe}$ (III) settled down the cells in the techniques. Juxtaposed with $\mathrm{H}_{2} \mathrm{O}_{2} / \mathrm{Fe}(\mathrm{II}), \mathrm{H}_{2} \mathrm{O}_{2} / \mathrm{Fe}$ (III) can eliminate algae efficaciously and dominate AOM liberation with smaller $\mathrm{H}_{2} \mathrm{O}_{2}$ $(50 \mu \mathrm{mol} / \mathrm{L})$ and $\mathrm{Fe}(\mathrm{III})(80 \mu \mathrm{mol} / \mathrm{L})$ injections, which proposes that small chemical use is appropriate for such concomitant oxidation/coagulation techniques. Zhang et al. [54] concluded that this is an encouraging technique for eliminating 

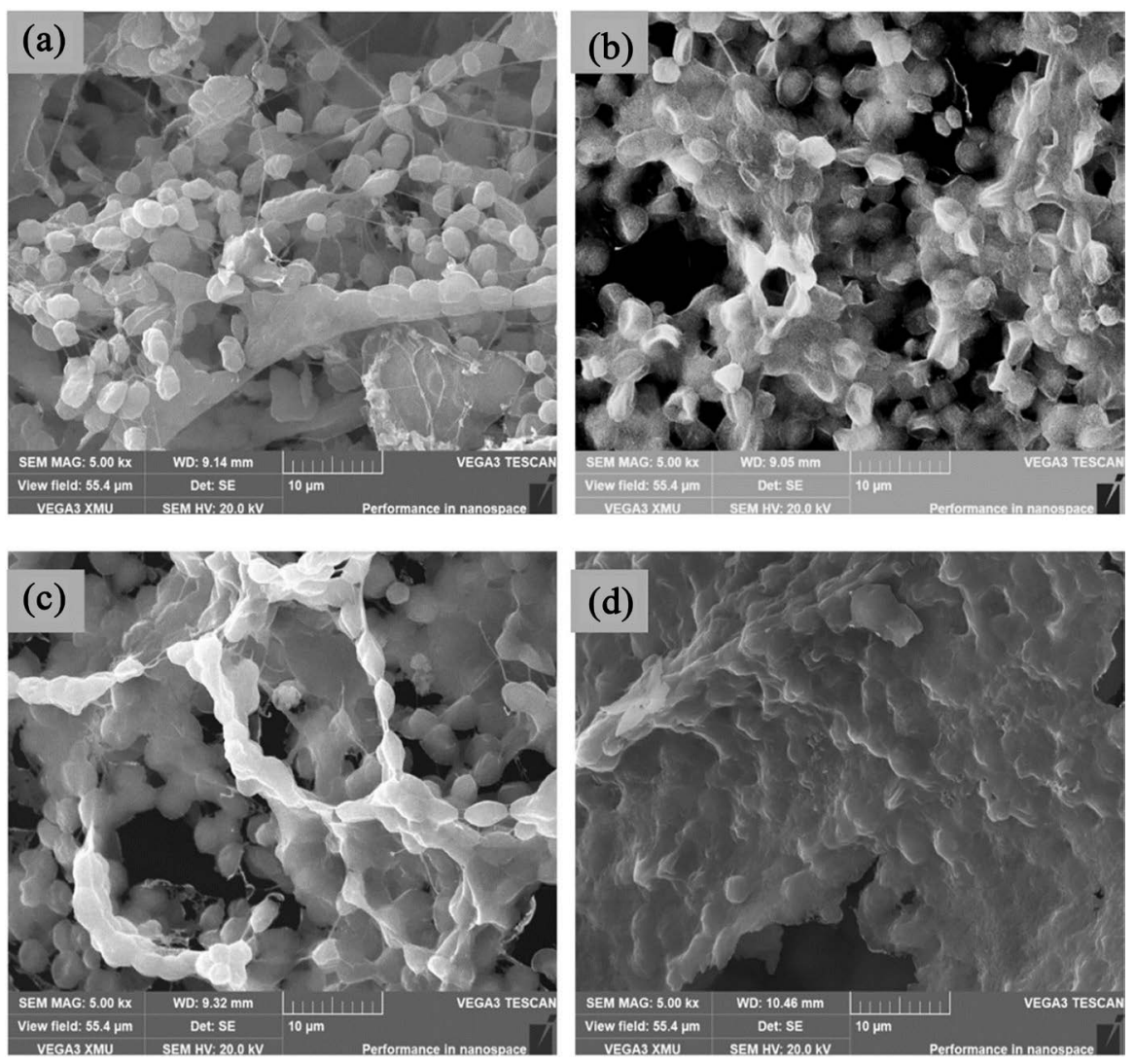

Figure 3. Scanning electronic microscopy (SEM) of flocs sedimentation with diverse Fe levels. $\mathrm{H}_{2} \mathrm{O}_{2}$ level is $100 \mu \mathrm{mol} / \mathrm{L}$, (a) $60 \mu \mathrm{mol} / \mathrm{L} \mathrm{Fe}(\mathrm{II})$, (b) $150 \mu \mathrm{mol} / \mathrm{L} \mathrm{Fe}$ (II) (c) $60 \mu \mathrm{mol} / \mathrm{L}$ $\mathrm{Fe}(\mathrm{III})$ (d) $150 \mu \mathrm{mol} / \mathrm{L} \mathrm{Fe}$ (III) [54].

algae from potable water in a pure and economical manner.

\section{Electrochemical Engineering for Algae Removal}

Ghernaout et al. [13] studied the microalgae removal from Ghrib Dam water via electroflotation (EF) using stainless steel electrodes. They illustrated that EF is outstanding in microalgae removal ( 100\%). They investigated the influences of numerous parameters. Future research must focus on microalgae lysis, toxin release and degradation due to EF treatment. Precautions must be taken such as reducing the applied voltage, increasing the residence time in the electrochemical device and adding a powdered activated carbon adsorption stage. The same researchers obtained also identical efficacy using electrocoagulation process [57] [58].

Some scientists also applied electrocoagulation and EF and obtained similar findings as well [59] [60] [61].

\section{Properties of Intracellular Organic Matter (IOM) and Its Reactivity vs. Hydroxyl Radicals}

Lee et al. [62] estimated the reactivity of IOM towards hydroxyl radicals $\left({ }^{\circ} \mathrm{OH}\right)$, a fundamental reaction species in advanced oxidation processes (AOPs) [63] [64] 
[65] [66]. IOM was extracted from two green algae, Chlamydomonas reinhardtii and Scenedesmus sp., and two blue-green algae, Anabaena sp. and M. aeruginosa employing a freeze-thaw procedure. The second-order rate constants of the extracted IOM with ${ }^{\bullet} \mathrm{OH}$ were determined as $7.95 \times 10^{8} \mathrm{M}_{\mathrm{C}}^{-1} \cdot \mathrm{s}^{-1}$ (C. reinhardtii), $6.71 \times 10^{8} \mathrm{M}_{\mathrm{C}}^{-1} \cdot \mathrm{s}^{-1}$ (Scenedesmus sp.), $4.02 \times 10^{8} \mathrm{M}_{\mathrm{C}}^{-1} \cdot \mathrm{s}^{-1}$ (Anabaena sp.), and $4.45 \times 10^{8} \mathrm{M}_{\mathrm{C}}^{-1} \cdot \mathrm{s}^{-1}$ (M. aeruginosa). Such rate constants were considerably bigger than values noted for dissolved $\mathrm{OM}$ in diverse water sources. This significates that IOM generation throughout algal bloom season can modify the ${ }^{\bullet} \mathrm{OH}$ water matrix demand and badly touch the efficiency of AOPs. To explore the physicochemical composition features of IOM and their link to the rate constants evaluated for the reaction between IOM and ${ }^{\bullet} \mathrm{OH}$, they employed liquid chromatography-organic carbon detection and fluorescence excitation-emission matrix \& parallel factor analysis. The IOM mostly composed of low molecular weight (LMW) matter and protein-related compounds, as evidenced LMW neutrals (38\% - 65\%), biopolymers (7\% - 19\%), and tryptophan-like compounds (74\% 94\%). Considering the composition properties of IOM, they concluded that the molecular weight and the occurrence of nitrogen-containing compounds are influential factors for assessing the reactivity of IOM with ${ }^{\bullet} \mathrm{OH}$.

\section{Blue-Green Algae: Ferrate(VI) Pre-Treatment and Following Chlorination}

Dong et al. [67] evaluated the influence of ferrate(VI) treatment on two blue-green algae, Chlorella sp. and Pseudanabaena limnetica, in eutrophic water. They established that $\mathrm{Fe}(\mathrm{VI})$ reduced the algal cells via provoking cell death, apoptosis, and lost integrity, and reduced AOM (in terms of total organic carbon) in water by oxidation and coagulation. Chlorination of the $\mathrm{Fe}(\mathrm{VI})$ pre-oxidized algal water samples formed halogenated DBPs; however, the levels of DBPs were smaller than those produced in the chlorinated samples without pre-treatment by $\mathrm{Fe}(\mathrm{VI})$. Bigger $\mathrm{Fe}(\mathrm{VI})$ injection, longer oxidation period, and alkaline $\mathrm{pH}$ were useful in dominating DBPs. In bromide-containing algal solutions, a disregarding quantity of bromo-DBPs was formed in the $\mathrm{Fe}(\mathrm{VI})$ pre-oxidation, and halogenated DBPs were mostly generated in the following chlorination.

\section{Acidified-Flocculation Process for Harvesting Microalgae}

Chemical flocculation stays viewed to be an overall low-cost and up-scalable technique for the harvesting of microalgae. Kim et al. [68] presented a flocculation procedure employing metal coagulant $\left(\mathrm{Fe}_{2}\left(\mathrm{SO}_{4}\right)_{3}\right)$ and sulfuric acid $\left(\mathrm{H}_{2} \mathrm{SO}_{4}\right)$ for the harvesting of Chlorella $s p$. KR-1, which gets over two major problems of pollution and reuse of coagulant (Figure 4). Decreasing $\mathrm{pH}$ successfully liberated residues fixed to the microalgae, and the residual acidic solution carrying recuperated ferric ions can be reused for harvesting up to three times with high, better-than $98 \%$ performances. Further, the acid-treated micro-algal biomass can be straight employed for lipid extraction without an additional catalyst. Ele- 
vated extraction yields of about $32 \%$ were obtained with fatty acids methyl ester (FAME) conversion performances of approximately $90 \%$. The combined procedure presented by Kim et al. [68] is anticipated to make the best use of the age-old yet effective harvesting means of flocculation, which can be a practical and economical option in micro-algal bio-refinery.

In the same direction, employing chitosan modified soil to flocculate and sediment algal cells has been seen as an encouraging procedure to counter cyanobacteria blooms in natural waters. However, the flocculation performance frequently changes with algal cells with diverse ZP [69] [70] related to varying development stages or water parameters. Li et al. [71] concentrated on the link between ZP of $M$. aeruginosa and its impact on the flocculation performance employing chitosan modified soil (Figure 5). Their findings proposed that the best reduction effectiveness was reached if the $\mathrm{ZP}$ was among -20.7 and $-6.7 \mathrm{mV}$ with an elimination performance of more than $80 \%$ in $30 \mathrm{~min}$ and a large floc size of $>350 \mu \mathrm{m}$. If the algal cells were more negatively charged than $-20.7 \mathrm{mV}$, the influence of chitosan modified soil was reduced $(<60 \%)$ because of the deficient charge density of chitosan to neutralize and destabilize the algal suspension. If

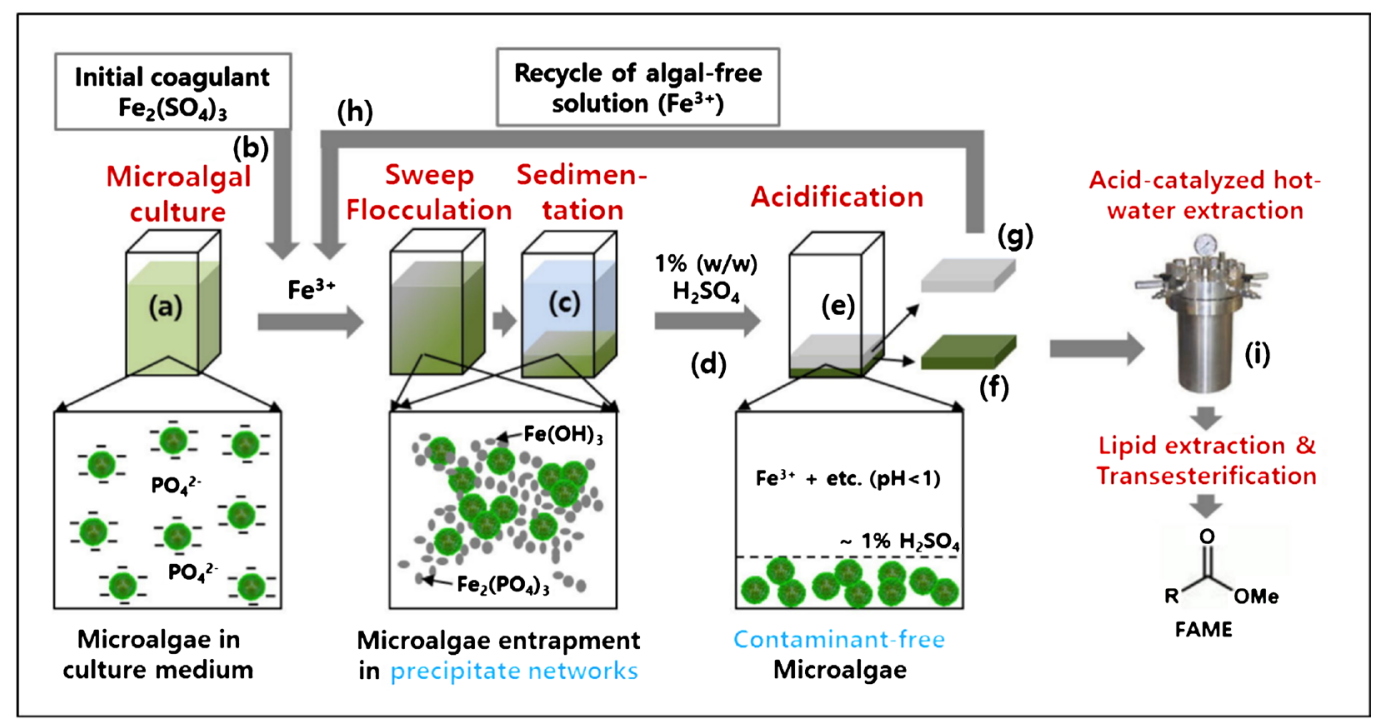

Figure 4. Overall experimental scheme of proposed system [68].
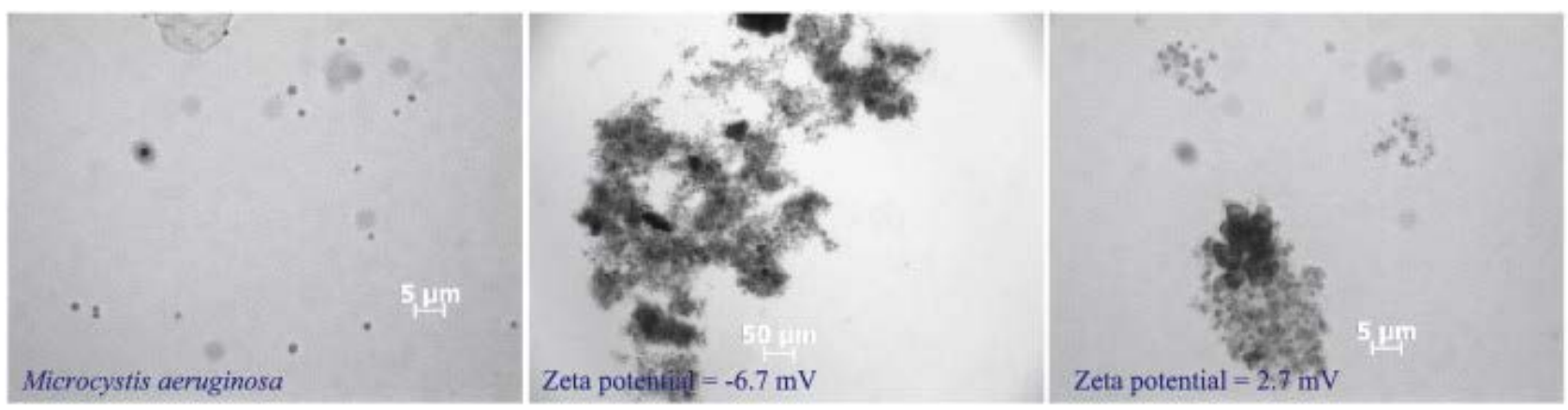

Figure 5. Images of floc structure of $M$. aeruginosa cells with varying zeta potential (ZP) after being flocculated by $2 \mathrm{mg} / \mathrm{L}$ chitosan modified $10 \mathrm{mg} / \mathrm{L}$ soil [71]. 
the algal cells were less negative than $-6.7 \mathrm{mV}$ or even positively charged, a small floc size $(<120 \mu \mathrm{m})$ was produced, which may be hard to sink below the usual water circumstances. Thus, controlling ZP furnished a doable tool to ameliorate the flocculation performance of chitosan modified soil and considerable advice for a workable technology of cyanobacteria bloom control.

\section{Decomposing Microcystins (MCs) Using Bacteria Acquired via Natural Media}

Bacteria separated via artificial media are usually unsustainable in bio-decomposing MCs in natural water. Li and Pan [72] investigated substitutional manners to separate MCs-decomposing microbes employing natural media. In comparison to two species (MS-1 and MS-2) separated from artificial media and the failure of bacterial colonies generation employing water extracts of sediment $(10 \%$, $\mathrm{w} / \mathrm{v}$ ), five colony species (WC-1 toWC-5) seemed to utilize concentrated water extracts of sediment that is 10 -fold enhancement of nutrient level. In the simulated bio-decomposition experiment, in the Lake Taihu water, with a continuous supply of MCs, a lag stage of 6 days was needed for MS-1 and M-2 to decompose $13 \%$ and $15 \%$ of the introduced MC-RR and MC-LR, respectively; however, the lag stage was only 3 days with around $44 \%$ and $31 \%$ reduction of the introduced MC-RR and MC-LR by WC- 1 to WC- 5 . Throughout the continuous supply test, decomposition of MCs via MS-1 and MS-2 paused after 3 days; however, decomposition of MCs via WC-1 to WC-5 persisted constantly during the 18 day test period with 2 to 6 -fold improvement of reduction rate. Further, 16S rRNA gene sequences and phylogenetic analysis depicted the capability to intensify species of MCs decomposing microbes if natural media were utilized. Such findings proposed that the augmented adaptability of microorganisms gained via concentrated natural media was in charge of the improved and persistent bio-decomposition below simulated natural water circumstances.

\section{Impact of Water Treatment Techniques on Cyanobacterial Integrity}

Numerous toxic and/or noxious cyanobacteria seem in nature with a filamentous, stacked cell arrangement called trichomes [73]. As aforesaid, even if water treatment could be regulated to maintain cyanobacterial cells intact and avert the liberation of poisonous and/or noxious compounds, several physicochemical stresses meet throughout the treatment technology may lead to trichome truncation, reducing treatment performance via letting single cells or short trichomes to attain the treated water. This makes it easy for toxic/noxious compounds as well as OM to come into the distribution system. Pestana et al. [73] performed examinations in a pilot and three full-scale water treatment plants to light the level of trichome truncation from one side to the other of the diverse unit techniques. They established that genera (Pseudanabaena, Planktolyngbya), with short trichomes (b10-12 cells per trichome), are hardly influenced via the unit 
processes (loss of one to four cells, respectively), whereas genera (Planktothrix, Geitlerinema, Dolichospermum) with longer trichomes (30+ cells per trichome) suffer from high degrees of truncation (up to 63, 30, and 56 cells per trichome, respectively). The existence of a rigid sheath and/or mucilaginous layer seems to provide some protection from truncation. They detected that some unit techniques modify the sensitivity or resilience of trichomes to disruption via physical stress. Certain genera (Planktothrix, Geitlerinema) were susceptible to pre-oxidation making them more liable to shear stress, while Dolichospermum sp. looks more solid after pre-oxidation. Whereas the possibility of toxicogenic genera breaking through into the treated water stays a true risk, Pestana et al. [73] did not note toxicogenic cyanobacteria. Such investigation underlines the necessity for plant engineers to monitor the arriving cyanobacterial composition in the raw water with a view to setting treatment variables and consequently restrict the possibility of toxic/noxious compound breakthrough.

\section{Trends towards Avoiding Chlorination}

As mentioned above, it is proved that chemical coagulants such as alum and pre-oxidation injecting chlorine can trigger demolition to algal cell integrity leading to the release of IOM, which involves taste, odor and toxicity to water [1] [33]. Ten years ago, a fundamental question was formulated in this direction [74]: "how the chemical water treatment with its chlorination (in the forms of pre-disinfection, disinfection, and post-disinfection) [75]-[81] and coagulation employing alum would be turned in a green water treatment?" As suggested, chlorination could be decreased to the disinfection (i.e., before sand filtration) averting pre-disinfection and keeping the post-disinfection [74] [82] [83] [84] [85] [86].

\section{Instead of Removing Algae, Harvesting Algae for Biodiesel Production}

As illustrated previously, the potable water treatment possesses many drawbacks like it could break the algae, that way liberating the taste- and odor-producing oils before the whole algae are eliminated from the treatment train. Ghernaout and Ghernaout [2] suggested the idea of algae recovery instead of its elimination in DWTP. Indeed, algae recuperation instead of its removal in DWTP remains an encouraging outlook especially if the surface water arrives from dams where algae blooms happen usually. Micro-algae remains a sustainable energy resource with a huge capacity for $\mathrm{CO}_{2}$ fixation. The micro-algae could be developed in photo-bioreactors or in open ponds. A fresh attracting domain of investigation would be fast and simultaneous algal biodiesel production with drinking water treatment in the biodiesel production/water treatment plant without chemicals. Algal cultivation requires light and space would be taken into account [2] [87] [88] [89]. 


\section{Conclusions}

This presented the major realizations obtained in the field of removing algae and controlling AOM. Special interest is accorded to the EC in terms of evaluation and enhancement. Electrochemical technology is discussed as it is used in the field of algae harvesting. The influence of water treatment technologies on cyanobacterial integrity is introduced. As the next tendencies, avoiding chlorine usage and algae harvesting for biodiesel production are suggested. From this work, the following conclusions can be drawn:

1) The hydrophobicity and flocculation features of cyanobacterial cells are closely linked to their extracellular polymeric substances (EPS). Throughout the treatment of potable water, the coagulation and elimination of EPS-wrapped cyanobacterial particles from natural water sources remain extremely hard. Sun et al. [90] followed a set of surface properties of cyanobacterial cells with diverse EPS portions to assess their impacts on the coagulation method. With the elimination of EPS, the coagulation effectiveness of cyanobacteria was gradually ameliorated. The intracellular MC liberation proved that the cyanobacterial cells in each EPS elimination stage were mainly intact with few broken cells. Consequently, the coagulation route of EPS-wrapped cyanobacterial particles was: the cyanobacterial cells were first peeled off through attraction by opposite charges from the coagulant, and then they were adsorbed before settling down. Such an investigation gives a scientific orientation for the elimination of cyanobacteria via enhancing coagulation.

2) The more recent references on algae treatment analyzed, the more realized that it is necessary to avoid disinfection (chlorination) before coagulation regardless of the nature of coagulant used.

\section{Acknowledgments}

This research has been funded by the Research Deanship of University of Ha'il, Saudi Arabia, through Project RG-191190.

\section{Conflicts of Interest}

The authors declare no conflicts of interest regarding the publication of this paper.

\section{References}

[1] Zhao, Z., Sun, W., Ray, A.K., Mao, T. and Ray, M.B. (2020) Coagulation and Disinfection By-Products Formation Potential of Extracellular and Intracellular Matter of Algae and Cyanobacteria. Chemosphere, 245, Article ID: 125669. https://doi.org/10.1016/j.chemosphere.2019.125669

[2] Ghernaout, D. and Ghernaout, B. (2012) On the Concept of the Future Drinking Water Treatment Plant: Algae Harvesting from the Algal Biomass for Biodiesel Production-A Review. Desalination and Water Treatment, 49, 1-18. https://doi.org/10.1080/19443994.2012.708191

[3] Chang, S.C., Li, C.H., Lin, J.J., Li, Y.H. and Lee, M.R. (2014) Effective Removal of Microcystis aeruginosa and Microcystin-LR Using Nanosilicate Platelets. Chemo- 
sphere, 99, 49-55. https://doi.org/10.1016/j.chemosphere.2013.09.036

[4] Pick, F.R. (2016) Blooming Algae: A Canadian Perspective on the Rise of Toxic Cyanobacteria. The Canadian Journal of Fisheries and Aquatic Sciences, 73, 1-10. https://doi.org/10.1139/cjfas-2015-0470

[5] Yan, Z.S., Liu, B., Qu, F.S., Ding, A., Liang, H., Zhao, Y. and Li, G.B. (2017) Control of Ultrafiltration Membrane Fouling Caused by Algal Extracellular Organic Matter (EOM) Using Enhanced Al Coagulation with Permanganate. Separation and Purification Technology, 172, 51-58. https://doi.org/10.1016/j.seppur.2016.07.054

[6] Faruqi, A., Henderson, M., Henderson, R.K., Stuetz, R., Gladman, B., McDowall, B. and Zamyadi, A. (2018) Removal of Algal Taste and Odour Compounds by Granular and Biological Activated Carbon in Full-Scale Water Treatment Plants. Water Science \& Technology Water Supply, 18, 1531-1544.

https://doi.org/10.2166/ws.2018.001

[7] Ghernaout, D., Badis, A., Braikia, G., Matâam, N., Fekhar, M., Ghernaout, B. and Boucherit, A. (2017) Enhanced Coagulation for Algae Removal in a Typical Algeria Water Treatment Plant. Environmental Engineering and Management Journal, 16, 2303-2315. https://doi.org/10.30638/eemj.2017.238

[8] Gonzalez-Torres, A., Putnam, J., Jefferson, B., Stuetz, R.M. and Henderson, R.K. (2014) Examination of the Physical Properties of Microcystis aeruginosa Flocs Produced on Coagulation with Metal Salts. Water Research, 60, 197-209. https://doi.org/10.1016/j.watres.2014.04.046

[9] Kellali, Y. and Ghernaout, D. (2019) Physicochemical and Algal Study of Three Dams (Algeria) and Removal of Microalgae by Enhanced Coagulation. Applied Engineering, 3, 56-64.

[10] Ghernaout, D., Moulay, S., Ait Messaoudene, N., Aichouni, M., Naceur, M.W. and Boucherit, A. (2014) Coagulation and Chlorination of NOM and Algae in Water Treatment: A Review. International Journal of Environmental Monitoring and Analysis, 2, 23-34. https://doi.org/10.11648/j.ijema.s.2014020601.14

[11] Ghernaout, D. and Ghernaout, B. (2012) Sweep Flocculation as a Second Form of Charge Neutralisation-A Review. Desalination and Water Treatment, 44, 15-28. https://doi.org/10.1080/19443994.2012.691699

[12] Ghernaout, B., Ghernaout, D. and Saiba, A. (2010) Algae and Cyanotoxins Removal by Coagulation/Flocculation: A Review. Desalination and Water Treatment, 20, 133-143. https://doi.org/10.5004/dwt.2010.1202

[13] Ghernaout, D., Benblidia, C. and Khemici, F. (2015) Microalgae Removal from Ghrib Dam (Ain Defla, Algeria) Water by Electroflotation Using Stainless Steel Electrodes. Desalination and Water Treatment, 54, 3328-3337. https://doi.org/10.1080/19443994.2014.907749

[14] Ghernaout, D. (2019) Electrocoagulation Process for Microalgal Biotechnology-A Review. Applied Engineering, 3, 85-94.

[15] Ghernaout, D., Al-Ghonamy, A.I., Boucherit, A., Ghernaout, B., Naceur, M.W., Ait Messaoudene, N., Aichouni, M., Mahjoubi, A.A. and Elboughdiri, N.A. (2015) Brownian Motion and Coagulation Process. American Journal of Environmental Protection, 4, 1-15. https://doi.org/10.11648/j.ajeps.s.2015040501.11

[16] Zhang, Y. and Fu, Q. (2018) Algal Fouling of Microfiltration and Ultrafiltration Membranes and Control Strategies: A Review. Separation and Purification Technology, 203, 193-208. https://doi.org/10.1016/j.seppur.2018.04.040

[17] Li, T., Dong, B., Liu, Z. and Chu, W. (2011) Characteristic of Algogenic Organic Matter and Its Effect on UF Membrane Fouling. Water Science \& Technology, 64, 
1685-1691. https://doi.org/10.2166/wst.2011.148

[18] Pivokonsky, M., Naceradska, J., Kopecka, I., Baresova, M., Jefferson, B., Li, X. and Henderson, R.K. (2016) The Impact of Algogenic Organic Matter on Water Treatment Plant Operation and Water Quality: A Review. Critical Reviews in Environmental Science and Technology, 46, 291-335.

https://doi.org/10.1080/10643389.2015.1087369

[19] Ghernaout, D., Alshammari, Y., Alghamdi, A., Aichouni, M., Touahmia, M. and Ait Messaoudene, N. (2018) Water Reuse: Extenuating Membrane Fouling in Membrane Processes. International Journal of Environmental Chemistry, 2, 1-12. https://doi.org/10.11648/j.ajche.20180602.12

[20] Ait Messaoudene, N., Naceur, M.W., Ghernaout, D., Alghamdi, A. and Aichouni, M. (2018) On the Validation Perspectives of the Proposed Novel Dimensionless Fouling Index. International Journal of Advances in Applied Sciences, 5, 116-122. https://doi.org/10.21833/ijaas.2018.07.014

[21] Ghernaout, D. (2019) Brine Recycling: Towards Membrane Processes as the Best Available Technology. Applied Engineering, 3, 71-84.

[22] Ghernaout, D. and El-Wakil, A. (2017) Requiring Reverse Osmosis Membranes Modifications: An Overview. American Journal of Chemical Engineering, 5, 81-88. https://doi.org/10.11648/j.ajche.20170504.15

[23] Boucherit, A., Moulay, S., Ghernaout, D., Al-Ghonamy, A.I., Ghernaout, B., Naceur, M.W., Ait Messaoudene, N., Aichouni, M., Mahjoubi, A.A. and Elboughdiri, N.A. (2015) New Trends in Disinfection By-Products Formation upon Water Treatment. Journal of Research \& Developments in Chemistry, 2015, Article ID: 628833. https://doi.org/10.5171/2015.628833

[24] Ghernaout, D. and Elboughdiri, N. (2020) Disinfection By-Products: Presence and Elimination in Drinking Water. Open Access Library Journal, 7, e6140.

[25] Ghernaout, D., Naceur, M.W. and Aouabed, A. (2011) On the Dependence of Chlorine By-Products Generated Species Formation of the Electrode Material and Applied Charge during Electrochemical Water Treatment. Desalination, 270, 9-22. https://doi.org/10.1016/j.desal.2011.01.010

[26] Zaouri, N., Gutierrez, L., Dramas, L., Garces, D. and Croue, J.-P. (2017) Interfacial Interactions between Skeletonema costatum Extracellular Organic Matter and Metal Oxides: Implications for Ceramic Membrane Filtration. Water Research, 116, 194-202. https://doi.org/10.1016/j.watres.2017.03.034

[27] Ghernaout, D. and Ghernaout, B. (2010) From Chemical Disinfection to Electrodisinfection: The Obligatory Itinerary? Desalination and Water Treatment, 16, 156-175. https://doi.org/10.5004/dwt.2010.1085

[28] Ghernaout, D. (2017) Microorganisms' Electrochemical Disinfection Phenomena. EC Microbiology, 9, 160-169.

[29] Ghernaout, D. and Elboughdiri, N. (2019) Mechanistic Insight into Disinfection Using Ferrate(VI). Open Access Library Journal, 6, e5946.

[30] Ghernaout, D. and Elboughdiri, N. (2019) Water Disinfection: Ferrate(VI) as the Greenest Chemical-A Review. Applied Engineering, 3, 171-180.

[31] Tomlinson, A., Drikas, M. and Brookes, J.D. (2016) The Role of Phytoplankton as Precursors for Disinfection By-Product Formation upon Chlorination. Water Research, 102, 229-240. https://doi.org/10.1016/j.watres.2016.06.024

[32] Ghernaout, D., Ghernaout, B. and Kellil, A. (2009) Natural Organic Matter Removal and Enhanced Coagulation as a Link between Coagulation and Electrocoagulation. Desalination and Water Treatment, 2, 203-222. 
https://doi.org/10.5004/dwt.2009.116

[33] Chow, C.W.K., Drikas, M., House, J., Burch, M.D. and Velzeboer, R.M.A. (1999) The Impact of Conventional Water Treatment Processes on Cells of the Cyanobacterium Microcystis aeruginosa. Water Research, 33, 3253-3262. https://doi.org/10.1016/S0043-1354(99)00051-2

[34] Lin, J.-L., Hua, L.-C., Hung, S.K. and Huang, C. (2018) Algal Removal from Cyanobacteria-Rich Waters by Preoxidation-Assisted Coagulation-Flotation: Effect of Algogenic Organic Matter Release on Algal Removal and Trihalomethane Formation. Journal of Environmental Sciences, 63, 147-155. https://doi.org/10.1016/j.jes.2017.02.007

[35] Alshammari, Y., Ghernaout, D., Aichouni, M. and Touahmia, M. (2018) Improving Operational Procedures in Riyadh's (Saudi Arabia) Water Treatment Plants Using Quality Tools. Applied Engineering, 2, 60-71.

[36] Li, M., Nkrumah, P.N. and Xiao, M. (2014) Biochemical Composition of Microcystis aeruginosa Related to Specific Growth Rate: Insight into the Effects of Abiotic Factors. Inland Waters, 4, 357-362. https://doi.org/10.5268/IW-4.4.710

[37] Wan, C., Alam, M.A., Zhao, X.-Q., Zhang, X.-Y., Guo, S.-L., Ho, S.-H., Chang, J.-S. and Bai, F.-W. (2015) Current Progress and Future Prospect of Microalgal Biomass Harvest Using Various Flocculation Technologies. Bioresource Technology, 18, 251-257. https://doi.org/10.1016/j.biortech.2014.11.081

[38] Ghernaout, D. (2017) Entropy in the Brownian Motion (BM) and Coagulation Background. Colloid and Surface Science, 2, 143-161.

[39] Ghernaout, D., Simoussa, A., Alghamdi, A., Ghernaout, B., Elboughdiri, N., Mahjoubi, A., Aichouni, M. and El-Wakil, A.A.E. (2018) Combining Lime Softening with Alum Coagulation for Hard Ghrib Dam Water Conventional Treatment. International Journal of Advanced and Applied Sciences, 5, 61-70. https://doi.org/10.21833/ijaas.2018.05.008

[40] Takaara, T., Sano, D., Konno, H. and Omura, T. (2007) Cellular Proteins of Microcystis aeruginosa Inhibiting Coagulation with Polyaluminum Chloride. Water Research, 41, 1653-1658. https://doi.org/10.1016/j.watres.2007.01.035

[41] Garzon-Sanabria, A.J., Ramirez-Caballero, S.S., Moss, F.E. and Nikolov, Z.L. (2013) Effect of Algogenic Organic Matter (AOM) and Sodium Chloride on Nannochloropsis salina Flocculation Efficiency. Bioresource Technology, 143, 231-237. https://doi.org/10.1016/j.biortech.2013.05.125

[42] Ghernaout, D. (2014) The Hydrophilic/Hydrophobic Ratio vs. Dissolved Organics Removal by Coagulation-A Review. Journal of King Saud University-Science, 26, 169-180. https://doi.org/10.1016/j.jksus.2013.09.005

[43] Tang, X.M., Zheng, H.L., Gao, B.Y., Zhao, C.L., Liu, B.Z., Chen, W. and Guo, J.S. (2017) Interactions of Specific Extracellular Organic Matter and Polyaluminum Chloride and Their Roles in the Algae-Polluted Water Treatment. Journal of Hazardous Materials, 332, 1-9. https://doi.org/10.1016/j.jhazmat.2017.02.060

[44] Leloup, M., Pallier, V., Nicolau, R. and Feuillade-Cathalifaud, G. (2015) Assessing Transformations of Algal Organic Matter in the Long-Term: Impacts of HumificationLike Processes. International Journal of Molecular Sciences, 16, 18096-18110. https://doi.org/10.3390/ijms160818096

[45] Goslan, E.H., Seigle, C., Purcell, D., Henderson, R., Parsons, S.A., Jefferson, B. and Judd, S.J. (2017) Carbonaceous and Nitrogenous Disinfection By-Product Formation from Algal Organic Matter. Chemosphere, 170, 1-9.

https://doi.org/10.1016/j.chemosphere.2016.11.148 
[46] Djezzar, S., Ghernaout, D., Cherifi, H., Alghamdi, A., Ghernaout, B. and Aichouni, M. (2018) Conventional, Enhanced, and Alkaline Coagulation for Hard Ghrib Dam (Algeria) Water. World Journal of Applied Chemistry, 3, 41-55. https://doi.org/10.11648/j.wjac.20180302.12

[47] Ghernaout, D. and Elboughdiri, N. (2020) Electrocoagulation Process in the Context of Disinfection Mechanism. Open Access Library Journal, 7, e6083.

[48] Ghernaout, D. and Elboughdiri, N. (2020) Strategies for Reducing Disinfection By-Products Formation during Electrocoagulation. Open Access Library Journal, 7, e6076. https://doi.org/10.4236/oalib.1106076

[49] Ghernaout, D. (2019) Disinfection via Electrocoagulation Process: Implied Mechanisms and Future Tendencies, EC Microbiology, 15, 79-90.

[50] Sun, Y., Zhou, S., Chiang, P.-C. and Shah, K.J. (2019) Evaluation and Optimization of Enhanced Coagulation Process: Water and Energy Nexus. Water-Energy Nexus, 2, 25-36. https://doi.org/10.1016/j.wen.2020.01.001

[51] Ghernaout, D. (2019) Greening Cold Fusion as an Energy Source for Water Treatment Distillation-A Perspective. American Journal of Quantum Chemistry and Molecular Spectroscopy, 3, 1-5.

[52] Liu, B., Qu, F., Chen, W., Liang, H., Wang, T., Cheng, X., Yu, H., Li, G. and Van der Bruggen, B. (2017) Microcystis aeruginosa-Laden Water Treatment Using Enhanced Coagulation by Persulfate/Fe(II), Ozone and Permanganate: Comparison of the Simultaneous and Successive Oxidant Dosing Strategy. Water Research, 125, 72-80. https://doi.org/10.1016/j.watres.2017.08.035

[53] Lin, J.-L. and Ika, A.R. (2020) Minimization of Halogenated DBP Precursors by Enhanced PACl Coagulation: The Impact of Organic Molecule Fraction Changes on DBP Precursors Destabilization with Al Hydrates. Science of the Total Environment, 703, Article ID: 134936. https://doi.org/10.1016/j.scitotenv.2019.134936

[54] Zhang, X., Ma, Y., Tang, T., Xiong, Y. and Dai, R. (2020) Removal of Cyanobacteria and Control of Algal Organic Matter by Simultaneous Oxidation and Coagulation-Comparing the $\mathrm{H}_{2} \mathrm{O}_{2} / \mathrm{Fe}(\mathrm{II})$ and $\mathrm{H}_{2} \mathrm{O}_{2} / \mathrm{Fe}$ (III) Processes. Science of the Total Environment, 720, Article ID: 137653. https://doi.org/10.1016/j.scitotenv.2020.137653

[55] Ghernaout, D. and Elboughdiri, N. (2020) UV-C/ $\mathrm{H}_{2} \mathrm{O}_{2}$ and Sunlight $/ \mathrm{H}_{2} \mathrm{O}_{2}$ in the Core of the Best Available Technologies for Dealing with Present Dares in Domestic Wastewater Reuse. Open Access Library Journal, 7, e6161. https://doi.org/10.4236/oalib.1106161

[56] Ghernaout, D., Elboughdiri, N. and Ghareba, S. (2020) Fenton Technology for Wastewater Treatment: Dares and Trends. Open Access Library Journal, 7, e6045. https://doi.org/10.4236/oalib.1106045

[57] Ghernaout, D., Badis, A., Ghernaout, B. and Kellil, A. (2008) Application of Electrocoagulation in Escherichia coli Culture and Two Surface Waters. Desalination, 219, 118-125. https://doi.org/10.1016/j.desal.2007.05.010

[58] Ghernaout, D., Naceur, M.W. and Ghernaout, B. (2011) A Review of Electrocoagulation as a Promising Coagulation Process for Improved Organic and Inorganic Matters Removal by Electrophoresis and Electroflotation. Desalination and Water Treatment, 28, 287-320. https://doi.org/10.5004/dwt.2011.1493

[59] Gao, S., Yang, J., Tian, J., Ma, F., Tu, G. and Du, M. (2010) Electro-CoagulationFlotation Process for Algae Removal. Journal of Hazardous Materials, 177, 336-343. https://doi.org/10.1016/j.jhazmat.2009.12.037 
[60] Kim, J., Ryu, B.-G., Kim, K., Kim, B.-K., Han, J.-I. and Yang, J.-W. (2012) Continuous Microalgae Recovery Using Electrolysis: Effect of Different Electrode Pairs and Timing of Polarity Exchange. Bioresource Technology, 123, 164-170. https://doi.org/10.1016/j.biortech.2012.08.010

[61] de la Fuente, A., Muro-Pastor, A.M., Merchán, F., Madrid, F., Pérez-Martínez, J.I. and Undabeytia, T. (2019) Electrocoagulation/Flocculation of Cyanobacteria from Surface Waters. Journal of Cleaner Production, 238, Article ID: 117964. https://doi.org/10.1016/j.jclepro.2019.117964

[62] Lee, D., Kwon, M., Ahn, Y., Jung, Y., Nam, S.-N., Choi, I.-H. and Kang, J.-W. (2018) Characteristics of Intracellular Algogenic Organic Matter and Its Reactivity with Hydroxyl Radicals. Water Research, 144, 13-25. https://doi.org/10.1016/j.watres.2018.06.069

[63] Ghernaout, D. (2013) Advanced Oxidation Phenomena in Electrocoagulation Process: A Myth or a Reality? Desalination and Water Treatment, 51, 7536-7554. https://doi.org/10.1080/19443994.2013.792520

[64] Ghernaout, D. (2019) Virus Removal by Electrocoagulation and Electrooxidation: New Findings and Future Trends. Journal of Environmental Science and Allied Research, 85-90.

[65] Ghernaout, D. and Elboughdiri, N. (2020) Advanced Oxidation Processes for Wastewater Treatment: Facts and Future Trends. Open Access Library Journal, 7, e6139.

[66] Ghernaout, D. and Naceur, M.W. (2011) Ferrate(VI): In Situ Generation and Water Treatment-A Review. Desalination and Water Treatment, 30, 319-332. https://doi.org/10.5004/dwt.2011.2217

[67] Dong, F., Liu, J., Li, C., Lin, Q., Zhang, T., Zhang, K. and Sharma, V.K. (2019) Ferrate(VI) Pre-Treatment and Subsequent Chlorination of Blue-Green Algae: Quantification of Disinfection Byproducts. Environment International, 133, Article ID: 105195. https://doi.org/10.1016/j.envint.2019.105195

[68] Kim, D.-Y., Lee, K., Lee, J., Lee, Y.-H., Han, J.-I., Park, J.-Y. and Oh, Y.-K. (2017) Acidified-Flocculation Process for Harvesting of Microalgae: Coagulant Reutilization and Metal-Free-Microalgae Recovery. Bioresource Technology, 239, 190-196. https://doi.org/10.1016/j.biortech.2017.05.021

[69] Ghernaout, D., Al-Ghonamy, A.I., Naceur, M.W., Boucherit, A., Messaoudene, N.A., Aichouni, M., Mahjoubi, A.A. and Elboughdiri, N.A. (2015) Controlling Coagulation Process: From Zeta Potential to Streaming Potential. American Journal of Environmental Protection, 4, 16-27. https://doi.org/10.11648/j.ajeps.s.2015040501.12

[70] Ghernaout, D. and Boucherit, A. (2015) Review of Coagulation's Rapid Mixing for NOM Removal. Journal of Research \& Developments in Chemistry, 2015, Article ID: 92651. https://doi.org/10.5171/2015.926518

[71] Li, L., Zhang, H. and Pan, G. (2015) Influence of Zeta Potential on the Flocculation of Cyanobacteria Cells Using Chitosan Modified Soil. Journal of Environmental Sciences, 28, 47-53. https://doi.org/10.1016/j.jes.2014.04.017

[72] Li, H. and Pan, G. (2014) Enhanced and Continued Degradation of Microcystins Using Microorganisms Obtained through Natural Media. The Journal of Microbiological Methods, 96, 73-80. https://doi.org/10.1016/j.mimet.2013.11.005

[73] Pestana, C.J., Capelo-Neto, J., Lawton, L., Oliveira, S., Carloto, I. and Linhares, H.P. (2019) The Effect of Water Treatment Unit Processes on Cyanobacterial Trichome Integrity. Science of the Total Environment, 659, 1403-1414. 
https://doi.org/10.1016/j.scitotenv.2018.12.337

[74] Ghernaout, D., Ghernaout, B. and Naceur, M.W. (2011) Embodying the Chemical Water Treatment in the Green Chemistry-A Review. Desalination, 271, 1-10. https://doi.org/10.1016/j.desal.2011.01.032

[75] Ghernaout, D. (2017) Water Treatment Chlorination: An Updated Mechanistic Insight Review. Chemistry Research Journal, 2, 125-138.

[76] Ghernaout, D., Alghamdi, A., Aichouni, M. and Touahmia, M. (2018) The Lethal Water Tri-Therapy: Chlorine, Alum, and Polyelectrolyte. World Journal of Applied Chemistry, 3, 65-71. https://doi.org/10.11648/j.wjac.20180302.14

[77] Ghernaout, D. and Elboughdiri, N. (2020) Is Not It Time to Stop Using Chlorine for Treating Water? Open Access Library Journal, 7, e6007.

[78] Ghernaout, D. (2017) Environmental Principles in the Holy Koran and the Sayings of the Prophet Muhammad. American Journal of Environmental Protection, 6, 75-79. https://doi.org/10.11648/j.ajep.20170603.13

[79] Ghernaout, D. (2018) Disinfection and DBPs Removal in Drinking Water Treatment: A Perspective for a Green Technology. International Journal of Advances in Applied Sciences, 5, 108-117. https://doi.org/10.21833/ijaas.2018.02.018

[80] Ghernaout, D., Touahmia, M. and Aichouni, M. (2019) Disinfecting Water: Electrocoagulation as an Efficient Process. Applied Engineering, 3, 1-12.

[81] Ghernaout, D., Aichouni, M. and Touahmia, M. (2019) Mechanistic Insight into Disinfection by Electrocoagulation-A Review. Desalination and Water Treatment, 141, 68-81. https://doi.org/10.5004/dwt.2019.23457

[82] Ghernaout, D., Alghamdi, A. and Ghernaout, B. (2019) Microorganisms' Killing: Chemical Disinfection vs. Electrodisinfection. Applied Engineering, 3, 13-19.

[83] Ghernaout, D. (2019) Greening Electrocoagulation Process for Disinfecting Water. Applied Engineering, 3, 27-31.

[84] Ghernaout, D. (2019) Electrocoagulation and Electrooxidation for Disinfecting Water: New Breakthroughs and Implied Mechanisms. Applied Engineering, 3, 125-133.

[85] Ghernaout, D. and Elboughdiri, N. (2019) Electrocoagulation Process Intensification for Disinfecting Water-A Review. Applied Engineering, 3, 140-147.

[86] Ghernaout, D. and Elboughdiri, N. (2019) Iron Electrocoagulation Process for Disinfecting Water-A Review. Applied Engineering, 3, 154-158.

[87] Al Arni, S., Amous, J. and Ghernaout, D. (2019) On the Perspective of Applying of a New Method for Wastewater Treatment Technology: Modification of the Third Traditional Stage with Two Units, One by Cultivating Microalgae and Another by Solar Vaporization. International Journal of Environmental Sciences \& Natural Resources, 16, Article ID: 555934. https://doi.org/10.19080/IJESNR.2019.16.555934

[88] Ghernaout, D., Alghamdi, A., Touahmia, M., Aichouni, M. and Ait Messaoudene, N. (2018) Nanotechnology Phenomena in the Light of the Solar Energy. Journal of Energy, Environmental \& Chemical Engineering, 3, 1-8. https://doi.org/10.11648/j.jeece.20180301.11

[89] Ghernaout, D. (2013) The Best Available Technology of Water/Wastewater Treatment and Seawater Desalination: Simulation of the Open Sky Seawater Distillation. Green and Sustainable Chemistry, 3, 68-88. https://doi.org/10.4236/gsc.2013.32012

[90] Sun, F., Zhang, H., Qian, A., Yu, H., Xu, C., Pan, R. and Shi, Y. (2020) The Influence of Extracellular Polymeric Substances on the Coagulation Process of Cyanobacteria. Science of the Total Environment, 720, Article ID: 137573.

https://doi.org/10.1016/j.scitotenv.2020.137573 